Nadwa | Jurnal Pendidikan Islam

Vol. 9, Nomor 1, April 2015

\title{
Peran Guru Bimbingan Konseling dalam Membina Kecerdasan Emosional dan Spiritual Siswa Berkebutuhan Khusus
}

\author{
Adita Pramanasari dan Zainal Arifin \\ Universitas Islam Negeri Sunan Kalijaga Yogyakarta \\ E-mail: derizzain@yahoo.co.id
}

\begin{abstract}
Abstrak
Latar belakang penelitian ini adalah kebutuhan Siswa Berkebutuhan Khusus (SBK) di SMP PGRI Kasihan akan penanganan ekstra dari guru Bimbingan Konseling (BK) dalam pengembangan Kecerdasan Emosional dan Spiritual (ESQ). Hasil penelitian menunjukkan: Pertama, SBK secara emosional belum mampu mengelola emosi, namun mampu membina hubungan sosial dengan baik. Secara spiritual, SBK belum mampu menjalankan ibadah dengan baik, namun mampu berbuat baik kepada kedua orang tua. Kedua, Peran guru Bimbingan Konseling (BK) dalam membina ESQ sebagai: komunikator, pendamping, motivator dan penasehat. Ketiga, faktor penghambat pelaksanaan BK meliputi: perbedaan latar belakang keluarga siswa, dan perbedaan karakteristik individu siswa. Sedangkan faktor pendukungnya meliputi: semangat kerja guru BK dalam memberikan bimbingan, dan pendampingan, dan wali murid.
\end{abstract}

Kata kunci: Guru Bimbingan Konseling (BK), Kecerdasan Emosional dan Spiritual (ESQ), Siswa Berkebutuhan Khusus (SBK)

\begin{abstract}
The background of this research is the need for Students with Special Needs (SBK) in SMP PGRI will Pity the extra handling of teacher Counseling (BK) in the development of Emotional and Spiritual Intelligence (ESQ). The results showed: First, SBK is emotionally not able to manage their emotions, but capable of fostering social relationships with both. Spiritually, SBK has not been able to practice well, but was able to do good to both parents. Second, the role of teachers Counseling (BK) in fostering ESQ as: a communicator, facilitator, motivator and advisor. Third, the implementation of the BK inhibiting factors include: the student's family background differences, and differences in the characteristics of individual students. While supporting factors include: BK teacher morale in providing guidance and mentoring, and guardians.
\end{abstract}

Keywords: Teachers Counseling (BK), Emotional and Spiritual Intelligence (ESQ), Students with Special Needs (SBK) 


\section{Pendahuluan}

Bimbingan dan Konseling atau disingkat dengan BK sangat erat hubungannya dengan pendidikan yang dapat dilakukan pada lembaga pendidikan formal (sekolah/madrasah), keluarga, masyarakat, organisasi, industri, dan lain sebagainya. ${ }^{1}$ Dalam kurikulum KTSP, kedudukan BK semakin kuat untuk mendorong perkembangan pribadi siswa. ${ }^{2}$ Dalam kebijakan kurikulum pendidikan dasar dan menengah di Indonesia, keberadaan BK di lembaga pendidikan formal sangatlah penting. BK merupakan kebutuhan mandiri yang tak kalah penting dengan kebutuhan mata pelajaran yang diajarkan dalam kegiatan pembelajaran. ${ }^{3}$ Artinya, membentuk siswa yang berkompeten dalam penguasaan materi dan berkarakter pribadi insan kamil tidak cukup dengan kegiatan pembelajaran, dibutuhkan pula kegiatan bimbingan melalui layanan bimbingan dan konseling.

Pendidikan pada hakekatnya adalah usaha sadar dan terencana untuk mewujudkan suasana belajar dan proses pembelajaran agar peserta didik secara aktif mengembangkan potensi dirinya untuk memiliki kekuatan spiritual keagamaan, pengendalian diri, kepribadian, kecerdasan, akhlak mulia, serta keterampilan yang diperlukan dirinya, masyarakat, bangsa dan negara. ${ }^{4}$ Pendidikan memiliki peran yang sangat penting dalam membentuk pribadi unggul dan berkualitas baik dari segi jasmani maupun rohani. Pendidikan hendaknya menjamin peserta didik secara pribadi mendapatkan layanan yang dapat mengembangkan kepribadian mereka secara optimal. BK memiliki kontribusi yang sangat penting dalam pendidikan, yaitu membantu dalam mengembangkan kualitas kepribadian peserta didik agar menjadi pribadi yang dapat berkembang secara optimal. $^{5}$

Siswa adalah individu yang memiliki perbedaan antara satu dengan yang lainnya. Dalam perkembangannya, setiap diri siswa

\footnotetext{
${ }^{1}$ Tohirin, Bimbingan dan Konseling di Sekolah dan Madrasah (Jakarta: PT Raja Grafindo Persada, 2009), hal. 1.

${ }^{2}$ Anonim, Undang-Undang Republik Indonesia Nomor 20 Tahun 2003 tentang Sistem Pendidikan Nasional, pasal 17 ayat 2.

${ }^{3}$ Sigit Purnomo, Bimbingan Konseling dalam Ontologi (Yogyakarta: Gala Ilmu Semesta, 2011), hal. 1.

${ }^{4}$ Anonim, Undang-Undang Republik Indonesia Nomor 20 Tahun 2003 tentang Sistem Pendidikan Nasional, pasal 1 ayat 1 .

${ }^{5}$ Tohirin, Bimbingan dan Konseling..., hal. 5-6.
} 
dapat dipastikan memiliki masalah-masalah individu yang berbeda pula baik masalah pribadi, sosial maupun akademiknya. Masalahmasalah siswa di sekolah, dapat dikategorikan menjadi lima, yaitu: perkembangan individu; perbedaan individu (kecerdasan, hasil belajar, bakat, sikap, kebiasaan, pengetahuan, kepribadian, fisik, latar belakang lingkungan, dan lain-lain); kebutuhan individu (kasih sayang, harga diri, penghargaan, ingin dikenal, prestasi dan posisi, rasa aman dan perlindungan diri, dan lain-lain); penyesuaian diri dan kelainan tingkah laku; masalah belajar. ${ }^{6}$

Peran guru BK tentu tidak hanya sebatas membantu siswa dalam memecahkan permasalahan yang sedang dihadapinya, tetapi juga membantu mengembangkan kualitas pribadi siswa agar mampu berkembang secara optimal seperti yang telah dijelaskan diatas. Karena siswa merupakan individu yang sedang berkembang menuju dewasa, maka guru bimbingan konseling hendaknya mampu memberikan layanan bimbingan yang mengarah kepada keberhasilan perkembangan siswa baik dari aspek intelektual, emosi, spiritual, dan sosial.

Perkembangan emosi siswa belum sepenuhnya stabil karena mereka baru menuju pada perkembangan selanjutnya, yaitu tahap usia dewasa. Pada usia sekolah, siswa mulai belajar mengenai bagaimana cara mengendalikan dan mengontrol emosinya. Emosiemosi yang dialami siswa pada usia sekolah ini diantaranya adalah marah, takut, cemburu, iri hati, kasih sayang, rasa ingin tahu, dan kegembiraan. ${ }^{7}$ Emosi pada dasarnya mempengaruhi tindakan seseorang, rencana seketika untuk mengatasi masalah. Jika emosi tidak dapat dikendalikan dan dikelola dengan baik, maka siswa akan mengalami kesulitan emosional. Jika itu terjadi secara terus-menerus maka akan merugikan kemampuan intelektrual siswa, sehingga akan melumpuhkan kemampuan belajarnya. ${ }^{8}$

Siswa yang memiliki masalah emosi akan mengalami kesulitan belajar, kesulitan bergaul, dan kurang mampu mengendalikan emosinya. Kecerdaan Emosional (EQ) mempengaruhi keterampilan-

${ }^{6}$ Ibid., hal. 111-112.

${ }^{7}$ Syamsu Yusuf L.N, Psikologi Perkembangan Anak dan Remaja (Bandung: PT Remaja Rosdakarya, 2008), hal. 181.

${ }^{8}$ Daniel Goleman, Kecerdasan Emosional (Jakarta: PT Gramedia Pustaka Utama, 1996), hal. 36. 
keterampilan yang dimilikinya termasuk keterampilan intelektual, ${ }^{9}$ artinya, Kecerdasan Intelektual (IQ) bukan sepenuhnya faktor yang mempengaruhi keberhasilan individu dalam mencapai prestasi belajar maupun kesuksesan dalam hidupnya. Akan tetapi faktor yang paling dominan dalam mempengaruhi keberhasilan dan kesuksesan hidup seseorang adalah EQ. ${ }^{10}$

Selain kecerdasan intelektual dan emosional, diperlukan kemampuan yang lebih penting lagi yaitu Kecerdasan Spiritual (SQ). Hal ini dikarenakan kedua kecerdasan tersebut (IQ dan EQ) baru menyentuh pada dataran kejiwaan yang masih berdimensi keduniawian, sedangkan hal-hal yang berhubungan dengan Tuhan belum mampu terjawab. Oleh karena itu, kecerdasan spiritual menjadi satu kecerdasan yang mampu menjawab persoalan yang berhubungan dengan Tuhan. Kecerdasan spiritual mampu mengoptimalkan kecerdasan intelektual dan emosional seseorang. ${ }^{11}$

Toto Tasmara memahami bahwa kecerdasan spiritual didasarkan atas nilai-nilai agama, sebuah kecerdasan yang berpusat pada nilai keagamaan. Apapun langkah yang dijalankan terarah pada kecintaanya pada Allah. ${ }^{12}$ Kecerdasan Spiritual (SQ) bagi siswa diartikan sebagai kemampuan untuk menyadari makna dirinya dalam berhubungan dengan Tuhan. Membangun SQ berarti membangun kesadaran sebagai upaya mengembangkan kemampuan spiritual. Kemampuan mengatasi beban hidup baik dari yang ringan hingga yang berat. Dengan demikian kecerdasan spiritual menciptakan motivasi diri untuk menjalani aktivitas.

Kecerdasan Emosional dan Spiritual (ESQ) kini menjadi prioritas. Kecerdasan emosional dan spiritual menjadi bekal penting bagi siswa dalam mempersiapkan masa depan, termasuk keberhasilan secara akademis atau kecerdasan intelektual. Mengingat pentingnya kecerdasan emosional dan spiritual bagi anak usia sekolah, maka sudah sewajarnya menjadi tugas guru bimbingan konseling

\footnotetext{
${ }^{9}$ Muhibbin Syah, Psikologi Pendidikan dengan Pendekatan Baru (Bandung: PT Remaja Rosdakarya, 2006), hal. 89.

${ }^{10}$ Syamsu Yusuf L.N, Psikologi Perkembangan..., hal. 113.

11 Agus Nggermanto, Quantum Quotient; Kecerdasan Quantum Cara Praktis Melejitkan IQ, EQ, dan SQ yang Harmonis (Bandung: Nuansa, 2001), hal. 115-117.

12 Toto Tasmara, Kecerdasan Ruhaniah (Tracendental Intelegence) Membentuk Kepribadian yang Bertanggung Jawab, Profesional, dan Berakhlak (Jakarta: Gema Insani Press, 2001), hal. x.
} 
dalam membina dasar-dasar kecerdasan emosional dan mengembangkan kemampuan spiritual siswa.

Siswa Berkebutuhan Khusus (SBK) sangat membutuhkan BK dalam meningkatkan kemampuan emosional dan spiritualnya. Hal ini dikarenakan SBK memiliki perkembangan kepribadian dan tingkah laku yang berbeda satu sama lain. Siswa ini pastinya juga memiliki masalah-masalah individu seperti yang telah dijelaskan diatas, bahkan banyak diantara mereka yang memiliki keadaan pribadi yang kurang dinamis. Berbagai karakteristik anak berkebutuhan khusus membutuhkan penanganan ekstra dari guru BK dalam pengembangan kecerdasan emosional dan spiritual. Dalam hal ini guru BK diharapkan mampu membina kecerdasan emosional dan spiritual siswa berkebutuhan khusus agar nantinya mereka dapat berkembang dengan penuh percaya diri terhadap diri mereka sendiri, mampu mengenali, memahami, dan mengelola emosi dengan baik, serta memiliki kecerdasan spiritual yang matang.

SMP PGRI Kasihan Bantul merupakan lembaga pendidikan formal swasta dibawah naungan yayasan yang terletak di Ngestiharjo, Kasihan, Bantul, Yogyakarta. SMP PGRI Kasihan adalah salah satu sekolah inklusi yang menerima berbagai karakteristik siswa, baik siswa yang normal maupun siswa berkebutuhan khusus. Dari hasil wawancara dengan Ibu Suginingsih selaku guru Bimbingan dan Konseling di SMP PGRI Kasihan, beliau menjelaskan bahwa SMP PGRI Kasihan telah dipercaya oleh pemerintah untuk menjadi salah satu sekolah inklusi.

Proses pembelajaran di sekolah, baik SBK kelas VII, VIII, dan IX dijadikan satu atau dicampur dengan siswa normal lainnya. Hal ini dilakukan karena sekolah inklusi menerapkan pendidikan untuk semua tanpa terkecuali, baik siswa berkebutuhan khusus maupun siswa normal pada umumnya. Terdapat 39 siswa berkebutuhan khusus yang terdiri dari 16 siswa di kelas VII, 15 siswa di kelas VIII, dan 8 siswa di kelas IX. Karakteristik SBK yang ada di SMP PGRI Kasihan diantaranya adalah siswa autis, slow learner (lambat belajar), hiperaktif, dan cacat fisik. Banyak SBK yang memiliki keadaan pribadi yang kurang dinamis, ada siswa yang kurang percaya diri, mengganggu teman lain, menangis ketika ada sedikit 
gangguan, meniru tindakan orang lain, dan juga sulit dalam memahami pembelajaran. ${ }^{13}$

Siswa Berkebutuhan Khusus (SBK) di SMP PGRI Kasihan merupakan pribadi-pribadi yang unik dengan segala karakteristiknya. Dalam proses perkembangannya, siswa ini memiliki kepribadian yang kurang dinamis dan sangat memerlukan pendampingan ekstra dari guru mata pelajaran maupun guru bimbingan dan konseling. Terkait dengan masalah-masalah yang timbul akibat kurangnya Kecerdasan Emosional dan Spiritual (ESQ) siswa, maka peran guru BK dalam meningkatkan kecerdasan emosional dan spiritual sangat diperlukan untuk memberikan bimbingan terhadap siswa berkebutuhan khusus.

\section{Kecerdasan Emosional dan Spiritual (ESQ) SBK di SMP PGRI Kasihan Bantul Yogyakarta}

Karakteristik SBK di SMP PGRI Kasihan Bantul Yogyakarta diantaranya adalah autisme, kelainan pendengaran, disleksia, slow learner (lambat belajar/ kesulitan belajar), hiperaktif, dan cacat fisik. ${ }^{14}$ Kesulitan yang dialami siswa-siswa adalah rendahnya nilai akademik, tidak mudah memahami pelajaran, tidak bisa konsentrasi, kesulitan belajar, hiperaktif, suka mengganggu teman lain, terlalu banyak bercanda, suka menantang dan berani pada orang yang lebih tua, sulit berkomunikasi, pasif, manja dan penakut, tidak bisa merespon, kurang pendengaran, sulit berbicara, serta sulit membaca dan menulis. ${ }^{15}$

SBK autis sangat membutuhkan guru pendamping yang dapat memberikan bimbingan dan perhatian ekstra ketika di sekolah. Siswa autis tingkat berat akan sangat sulit berinteraksi dan berkomunikasi dengan orang lain karena mereka merasa berada di dalam duninya sendiri. Jadi saat guru menjelaskan pelajaran, guru pendampingnya akan membantu siswa autis ini untuk menulis dan mengikuti pelajaran. Begitu juga dengan siswa yang mengalami tunagrahita dan slow learner (kesulitan belajar) harus mendapatkan bimbingan dari guru pendamping untuk membantunya dalam

${ }^{13}$ Hasil wawancara prapenelitian dengan Guru Bimbingan Konseling Ibu Suginingsih pada tanggal 06 Januari 2015

${ }^{14}$ Hasil observasi di SMP PGRI Kasihan Bantul Yogyakarta pada tanggal 17 Februari 2015

${ }^{15}$ Hasil wawancara dengan Kepala Sekolah Ibu Titi Surarawati pada tanggal 20 Februari 2015 
mengikuti pembelajaran di kelas. Untuk siswa tunalaras, mereka harus mendapatkan arahan secara terus-menerus karena siswa ini mempunyai perilaku yang berlebihan seperti bersuara keras ketika berbicara dan memiliki ego yang tinggi. Namun disisi lain, siswa tunalaras ini memiliki kemampuan intelektual yang cukup tinggi dan mampu mengikuti pelajaran jika diarahkan dengan baik. ${ }^{16}$

Khusus untuk siswa autis tingkat berat seperti Alvin Maulana Ilman kelas VII E, ada guru pendamping khusus yang setiap waktu membimbing dan mengarahkan ketika berada di sekolah. Menurut Ibu Ida Farida selaku guru pendamping Alvin, siswa autis tingkat berat seperti Alvin sangat membutuhkan pendampingan khusus karena siswa ini sangat sulit untuk dikendalikan. Kerika sedang pembelajaran di kelas, ia semaunya sendiri, tidak mau menulis, berteriak-teriak, berjalan-jalan, dan sibuk dengan dunianya sendiri. Namun jika ada pendampingnya, ia akan menurut dengan apa yang dikatakan oleh pendampingnya. Karena mengalami kesulitan dalam pelajaran, maka Ibu Ida lebih memberikan perhatian dan bimbingan ekstra kepada Alvin agar ia berkemauan untuk menulis dan belajar. Menurut Ibu Ida, siswa autis seperti Alfin memiliki kelebihan tersendiri, ia memiliki kemauan yang besar untuk belajar jika diarahkan oleh orang yang dekat dengannya. Guru mata pelajaran umumnya memberikan pelajaran secara menyeluruh untuk semua siswanya, jadi sangat sulit untuk memperhatikan siswanya satu persatu. Keadaan ini yang membuat Ibu Ida dihadirkan di sekolah untuk mendampingi siswa khusus autis seperti Alvin. ${ }^{17}$

Goleman menyatakan bahwa terdapat lima unsur kecerdasan emosional yang sangat penting dimiliki oleh seorang siswa agar mereka dapat mengelola emosinya dengan baik. Unsur-unsur tersebut yaitu, kesadaran diri, mengelola emosi, memanfaatkan emosi secara produktif, empati, dan membina hubungan. Keterampilan emosional sangat menentukan bagaimana seseorang mampu menggunakan kemampuan-kemampuan lain yang dimilikinya, termasuk kemampuan intelektual. ${ }^{18}$

${ }^{16}$ Hasil wawancara dengan Guru Pendamping Siswa Berkebutuhan Khusus Ibu Yuni Asih pada tanggal 24 April 2015

17 Hasil wawancara dengan Guru Pendamping Siswa Berkebutuhan Khusus Autis (Alvin Maulana Ilman kelas VII E) pada tanggal 10 April 2015

${ }^{18}$ Daniel Goleman, Kecerdasan Emosional..., hal. 403. 


\section{Kondisi Kecerdasan Emosional (EQ)}

Kondisi Kecerdasan Emosional (EQ) Siswa Berkebutuhan Khusus (SBK) di SMP PGRI Kasihan diantaranya. Pertama, SBK kurang dapat memanfaatkan emosi dengan baik. Karakteristik emosional dan perilaku SBK di SMP PGRI Kasihan yang kurang stabil sangat mengganggu konsentrasi belajar kelas. Banyak SBK kesulitan belajar, sulit memahami pelajaran, dan sulit berkonsentrasi sehingga nilai akademiknya cenderung rendah. Kesulitan belajar dapat disebabkan kehilangan perhatian dan konsentrasi saat pelajaran berlangsung, seperti siswa autis suka bermain sendiri di tengah-tengah pembelajaran, siswa hiperaktif terlalu banyak bertanya tetapi tidak ada hubungannya dengan pelajaran, siswa pasif mudah bosan dengan pelajaran sehingga malas mendengarkan dan mencatat pelajaran, sedangkan siswa berkelainan pendengaran susah menangkap pelajaran. ${ }^{19}$ SBK mengaku kesulitan dalam memahami pelajaran karena beberapa alasan yaitu, penjelasan dari guru terlalu cepat, ada beberapa pelajaran yang sulit untuk dipelajari, dan susah mengikuti pelajaran karena tidak konsentrasi. ${ }^{20}$

Kedua, SBK belum mampu mengelola emosi dengan baik. Selain nilai akademik mereka yang dapat dikatakan rendah karena belum mampu memanfaatkan emosi secara produktif, SBK di SMP PGRI Kasihan juga kurang mampu mengelola emosinya, misal mudah marah dan tersinggung. Hal ini disebabkan karena mereka tidak terima dengan perkataan, tindakan, atau sikap siswa lain yang menghina, mengejek dan mengganggu mereka secara sengaja. Ada beberapa siswa yang memilih diam tidak menanggapi gangguan dari siswa lain karena mereka tidak ingin terjadi pertengkaran dan keributan di kelas. Sementara ada seorang siswa yang memilih melaporkan guru BK agar ditindaklanjuti dengan memberikan nasehat atau teguran yang mendidik. ${ }^{21}$ Siswa autis pun juga memiliki emosi yang kurang terkontrol, sehingga ketika ia mendapat gang-

19 Hasil wawancara dengan Guru Bimbingan dan Konseling Ibu Suginingsih pada tanggal 03 Maret 2015

${ }^{20}$ Hasil wawancara dengan Siswa-siswa Berkebutuhan Khusus di SMP PGRI Kasihan Bantul Yogyakarta pada tanggal 03, 10, 19, dan 20 Maret 2015

${ }^{21}$ Ibid., 
guan akan memberontak, mengamuk, dan membalas dengan tindakan tertentu. Siswa ini merasa tidak nyaman dengan adanya gangguan. ${ }^{22}$

Ketiga, SBK kurang percaya diri dan tidak berani menunjukkan potensi yang dimiliki. SBK di SMP PGRI Kasihan yang mengaku bahwa mereka merasa malu dan tidak berani ketika guru menyuruh untuk menjawab soal di depan kelas, kurang percaya diri dengan siswa lainnya, dan merasa minder dengan keadaan dirinya sendiri. ${ }^{23}$ SBK merasa dirinya berbeda dengan siswa lain karena memiliki kelainan tertentu sehingga membuat tidak percaya diri.

Keempat, SBK mampu membina hubungan sosial dengan baik. Dalam hal membina hubungan, SBK di SMP PGRI Kasihan tergolong siswa yang mudah bergaul. Hal ini dapat disimpulkan dari pernyataan mayoritas siswa yang menjelaskan bahwa mereka bermain dengan siapapun, tidak memilih-milih teman, memiliki banyak teman, dan suka berkumpul dengan semua teman. Walaupun masih ada dua siswa yang mengaku memiliki sedikit teman karena sifat pendiamnya. Sementara ada seorang siswa yang hanya memiliki satu orang teman karena menurutnya tidak ada yang ingin mau diajak bermain. ${ }^{24}$

Kelima, SBK memiliki sikap empati. SBK di SMP PGRI Kasihan memiliki rasa empati dan kepedulian yang cukup tinggi terhadap sesama. Hal ini dapat disimpulkan dari pernyataan mayoritas siswa yang mengaku bahwa mereka bersedia mendengarkan permasalahan teman orang lain yang ingin berbagi cerita. Siswa-siswa ini juga suka menolong dan membantu teman lain yang sedang kesusahan. Mereka memulai sikap positif ini dari hal yang mudah dan ringan seperti, mau mengerti kesedihan yang dirasakan orang lain, suka berbagi apapun yang dimilikinya, meminjami uang kepada teman yang kekurangan, membelikan bensin ketika motor temannya kehabisan bahan bakar, dan bersedia membantu ketika teman sedang berada dalam kesulitan. ${ }^{25}$

${ }^{22}$ Hasil wawancara dengan Guru Pendamping Siswa Berkebutuhan Khusus Autis Ibu Ida Farida pada tanggal 10 April 2015

${ }^{23}$ Hasil wawancara dengan Siswa-siswa Berkebutuhan Khusus di SMP PGRI Kasihan Bantul Yogyakarta pada tanggal 03, 10, 19, dan 20 Maret 2015

${ }^{24}$ Ibid.,

25 Ibid., 


\section{Kondisi Kecerdasan Spiritual (SQ)}

Muslim yang cerdas spiritualnya akan menjalani hidupnya sesuai dengan apa yang diajarkan agamanya. Sebagai orang Islam, mereka akan menjalankan hidup sesuai dengan kehendak Allah SWT dan menjauhi larangan-Nya. Seorang yang memiliki keterampilan spiritual akan menjalankan ibadahnya dan mengerjakan sesuatu dengan niat beribadah kepada Allah SWT. ${ }^{26}$ Kondisi SQ Siswa Berkebutuhan Khusus (SBK) di SMP PGRI Kasihan diantaranya:

Pertama, SBK belum mampu menjalankan ibadahnya dengan baik. Dalam hal menjalankan ibadah wajib dan sunnah, SBK di SMP PGRI Kasihan belum mampu menjalankan ibadah dengan sempurna. Menurut Ibu Suginingsih selaku guru BK siswa-siswa ini belum mampu untuk sholat, membaca surat-surat pendek, dan pengetahuan-pengetahuan keagamaan lainnya. ${ }^{27}$ Sedangkan menurut Ibu Yuni selaku guru pendamping SBK, siswa-siswa berkebutuhan khusus ini sangat kurang dalam ibadah sholat dan ibadah lainnya. Hal ini disebabkan oleh kurangnya perhatian orang tua yang mayoritas dari keluarga menengah kebawah sehingga harus bekerja keras untuk mencukupi kebutuhan rumah tangga. Mereka terlalu sibuk dengan pekerjaannya masing-masing sehingga tidak ada waktu untuk memperhatikan masalah anaknya dalam hal keagamaan. $^{28}$

Berdasarkan pernyataan dari SBK SMP PGRI Kasihan, beberapa siswa mengaku jarang sholat lima waktu. Bahkan ada yang tidak pernah sholat sama sekali dengan alasan karena tidak ada waktu, tidak sempat, dan malas. Walaupun demikian, ada tiga siswa yang mengerjakan sholat lima waktu. Siswa autis tingkat berat seperti Alvin kelas VII E jusru memiliki kemauan melakukan ibadah sholat wajib, namun untuk melakukan hal itu harus terus-

${ }^{26}$ Wahyudi Siswanto, dkk., Membentuk Kecerdasan Spiritual Anak; Pedoman Penting bagi Orang Tua dalam Mendidik Anak, (Jakarta: Amzah, 2010), hal. 13.

27 Hasil wawancara dengan Guru Bimbingan dan Konseling Ibu Suginingsih pada tanggal 03 Maret 2015

28 Hasil wawancara dengan Guru Pendamping Siswa Berkebutuhan Khusus Ibu Yuni Asih pada tanggal 24 April 2015 
menerus diarahkan dan diingatkan oleh keluarga dan guru pendampingnya. ${ }^{29}$ Dalam puasa ramadhan, SBK mengaku berpuasa walaupun tidak bisa penuh. Namun ada juga beberapa siswa yang masih tidak puasa karena berbagai alasan seperti tidak kuat, lupa tidak makan sahur, dan malas. ${ }^{30}$

Kedua, SBK belum mampu membaca Al-Qur'an. Al-Qur'an merupakan kalam Allah yang diturunkan kepada Nabi Muhammad SAW secara mutawatir. ${ }^{31}$ Allah menjadikan Al-Qur'an yang berisi petunjuknya sebagai parameter bagi setiap sikap dan tingkah laku dalam segala aspek kehidupan. Dalam hal penguasaan bacaan AlQur'an, SBK di SMP PGRI Kasihan tergolong siswa yang sangat kurang kemampuan. Menurut Ibu Nurkamila Anggraini selaku guru BK kelas VII, kesulitan siswa dalam membaca Al-Qur'an disebabkan oleh kurang perhatian orang tua. SBK tidak mampu melanjutkan belajar membaca Al-Qur'an dikarenakan berhenti mengikuti TPA. ${ }^{32}$ Beberapa SBK mengaku masih belajar Iqro'. Ada empat siswa yang rutin membaca Al-Qur'an setiap selesai sholat maghrib ataupun beberapa hari sekali. ${ }^{33}$ Selain itu menurut Ibu Ida guru pendamping khusus siswa autis (Alvin), siswa autis berat seperti Alvin justru memiliki daya ingat yang kuat sehingga mampu menghafal surat-surat pendek al-Qur'an dan doa sehari-hari. ${ }^{34}$

Ketiga, SBK kurang berakhlak atau berperilaku yang baik. SBK di SMP PGRI Kasihan sangat kurang dalam berperilaku baik. Misalnya, sering berbicara bohong kepada orang lain. Dari beberapa siswa yang menjadi informan, masih terdapat dua siswa yang mengaku telah terbiasa berbicara bohong kepada orang lain dan merasa nyaman melakukan kebiasaan tersebut. ${ }^{35}$ Menurut Ibu Suginingsih selaku guru BK, siswa-siswa ini juga bersikap tidak

29 Hasil wawancara dengan Guru Pendamping Siswa Berkebutuhan Khusus Autis Ibu Ida Farida pada tanggal 10 April 2015

${ }^{30}$ Hasil wawancara dengan Siswa-siswa Berkebutuhan Khusus di SMP PGRI Kasihan Bantul Yogyakarta pada tanggal 03, 10, 19, dan 20 Maret 2015

31 Acep Hermawan, 'Ulumul Qur'an; Ilmu untuk Memahami Wahyu, (Bandung: PT Remaja Rosdakarya, 2013), hal. 11.

${ }^{32}$ Hasil wawancara dengan Guru Bimbingan dan Konseling Ibu Nurkamila Anggraini pada tanggal 03 Maret 2015

${ }^{33}$ Hasil wawancara dengan Siswa-siswa Berkebutuhan Khusus di SMP PGRI Kasihan Bantul Yogyakarta pada tanggal 03, 10, 19, dan 20 Maret 2015

${ }^{34}$ Hasil wawancara dengan Guru Pendamping Siswa Berkebutuhan Khusus Autis Ibu Ida Farida pada tanggal 10 April 2015

${ }^{35}$ Ibid., 
sopan kepada bapak ibu guru, kurang mempunyai tata krama, berbicara kasar, serta tidak dapat mengontrol sikap dan perilakunya dengan baik. ${ }^{36}$

Keempat, SBK mampu berbuat baik kepada kedua orang tua (Birrul Walidain). Dalam Islam, birrul walidain berarti berbuat ihsan kepada kedua orangtua. ${ }^{37}$ Dalam hal berbakti kepada kedua orang tua, SBK di SMP PGRI Kasihan memiliki sikap yang cukup baik kepada kedua orang tua, misalnya SBK mengaku sayang kepada kedua orang tuanya, ingin membahagiakan, tidak ingin menjadi anak durhaka, tidak ingin membuat orang tua susah, berusaha taat dan patuh, serta berusaha agar kelak mampu berbalas budi kedua orangtua. Namun ada pula siswa yang merasa kecewa dengan kedua orangtuanya karena ditinggal bekerja selama 14 tahun. ${ }^{38}$

Kondisi ESQ Siswa Berkebutuhan Khusus (SBK) ini membutuhkan bimbingan dan perhatian ekstra dari pihak sekolah terutama guru BK dalam meningkatkan kemampuan emosional dan spiritualnya. Kemampuan emosional dan spiritual yang matang, akan membantu siswa berkembang secara optimal. Hal ini menjadi penting karena kecerdasan emosional dan spiritual yang lebih utama dalam membentuk kepribadian dan keberhasilan siswa di masa depan.

\section{Peran Guru BK dalam Membina ESQ Siswa Berkebutuhan Khusus (SBK) di SMP PGRI Kasihan Bantul Yogyakarta}

Proses pembelajaran SBK di SMP PGRI Kasihan dilakukan sama dengan proses pembelajaran untuk siswa normal di sekolahsekolah lain. Hal ini dikarenakan SMP PGRI Kasihan merupakan sekolah umum yang menerapkan pendidikan inklusi. Pembelajaran untuk SBK dijadikan satu (dicampur) dengan siswa normal lainnya baik kelas VII, VIII, dan IX. Namun mulai tahun pelajaran 2014-

36 Hasil wawancara dengan Guru Bimbingan dan Konseling Ibu Suginingsih pada tanggal 03 Maret 2015

37 Heri Gunawan, Keajaiban Berbakti kepada Kedua Orang Tua, (Bandung: PT Remaja Rosdakarya, 2014), hal. 2.

${ }^{38}$ Hasil wawancara dengan Siswa-siswa Berkebutuhan Khusus di SMP PGRI Kasihan Bantul Yogyakarta pada tanggal 03, 10, 19, dan 20 Maret 2015 
2015, SBK baru yang masuk pada tahun pelajaran tersebut dikhususkan (dikelompokkan) di kelas VII E. Kelas VII E ini semua siswanya tergolong SBK dengan karakteristik yang berbeda-beda. ${ }^{39}$

SMP PGRI Kasihan menerapkan identifikasi bagi siswa-siswa yang tergolong SBK. Ibu Titi selaku kepala sekolah menyatakan bahwa jika pada saat awal tahun pelajaran terdapat siswa yang terlihat normal namun setelah diidentifikasi selama proses pembelajaran berlangsung memiliki kelainan, maka akan dipindahkan ke kelas VII E yang semuanya SBK. Hal ini dilakukan agar mempermudah pelaksanaan proses pembelajaran bagi siswa berkebutuhan khusus. ${ }^{40}$

Walaupun proses pembelajaran yang berlangsung di SMP PGRI Kasihan serupa dengan sekolah-sekolah lain, namun SBK tetap membutuhkan perhatian ekstra dari guru mata pelajaran maupun guru BK. Guru menjelaskan pelajaran secara berulangulang agar siswa dapat memahami. SBK membutuhkan waktu yang lebih lama dibandingkan dengan siswa normal untuk dapat memahami materi. Siswa-siswa ini mayoritas mengalami kesulitan belajar/lambat belajar (slow learner). Siswa autis berat, perlu didampingi oleh guru pendamping karena kadang berperilaku di luar kendali. SMP PGRI Kasihan juga memiliki satu guru pendamping untuk semua SBK yang datang setiap hari Jum'at dan Sabtu. ${ }^{41}$

Layanan Bimbingan Konseling (BK) di SMP PGRI Kasihan dilaksanakan oleh dua orang guru BK yaitu Ibu Suginigsih dan Ibu Nurkamila Anggraini. BK untuk SBK dilakukan secara individu maupun kelompok. Bimbingan kelompok dilakukan di kelas saat jam pelajaran berlangsung. Sedangkan untuk bimbingan individu, guru BK melakukan identifikasi terhadap SBK yang menunjukkan masalah seperti membolos, berbicara kasar, berkelahi, dan kesulitan terhadap pelajaran. Bimbingan individu juga ditujukan kepada SBK yang mengalami perilaku yang tidak baik atau menyimpang. Ketika terjadi suatu masalah dengan siswa, guru BK menegur, menasehati,

${ }^{39}$ Hasil observasi di SMP PGRI Kasihan Bantul Yogyakarta pada tanggal 17 Februari 2015

${ }^{40}$ Hasil wawancara dengan Kepala Sekolah Ibu Titi Surarawati pada tanggal 20 Februari 2015

${ }^{41}$ Hasil observasi di SMP PGRI Kasihan Bantul Yogyakarta pada tanggal 17 Februari 2015 
mengarahkan, dan membimbing siswa agar berperilaku lebih baik dan mampu menyelesaikan masalahnya sendiri. ${ }^{42}$

Ketika terjadi suatu permasalahan, beberapa SBK di SMP PGRI Kasihan mendatangi guru BK untuk sharing agar mendapatkan solusi yang baik. Guru BK melakukan pendekatan dengan cara mengajak berbicara empat mata, mendengarkan permasalahan siswa, dan memberikan solusi atau membantu memecahkan masalah. Tugas guru BK adalah mendampingi dan membimbing SBK agar menjadi siswa yang mandiri. Ketika terjadi suatu masalah pada SBK, guru BK juga bekerja sama dengan guru wali kelas dan guru mata pelajaran untuk bersama-sama memecahkan kesulitan yang dialami siswa. ${ }^{43}$

Guru BK mencoba berinteraksi dengan cara berbicara pelan sesuai kemampuan siswa yang kesulitan mendengar dan autis. Guru BK secara kontinyu memberikan bimbingan dan motivasi kepada SBK kelas IX, khususnya untuk persiapan ujian nasional. Bimbingan ini diberikan di kelas ketika jam pelajaran berlangsung. ${ }^{44}$ Siswa berkebutuhan khusus di SMP PGRI Kasihan sangat membutuhkan layanan bimbingan dan konseling karena siswa ini memiliki perilaku dan kepribadian yang tidak stabil. Hal ini mengakibatkan siswa-siswa tersebut memiliki masalah-masalah emosional dan spiritual yang perlu dibina agar mereka mampu menjadi siswa yang cerdas secara emosional serta memiliki kemampuan spiritual yang matang.

Peran guru BK adalah membantu menyelesaikan permasalahan yang dialami siswa, mampu membimbing agar dapat berkembang dengan optimal. Hal ini dapat dilakukan dengan cara membantu siswa dalam meningkatkan kualitas pribadi mereka dari segi emosional dan spiritual. Untuk membantu para siswa mengembangkan ESQ, maka pemberian layanan BK harus dilaksanakan secara teamwork, antara konselor, guru bidang studi, dan kepala sekolah. ${ }^{45}$

Peran guru BK dalam membina ESQ bagi SBK di SMP PGRI Kasihan adalah sebagai: Pertama, Guru BK sebagai komunikator.

42 Hasil wawancara dengan Guru Bimbingan dan Konseling Ibu Suginingsih pada tanggal 03 Maret 2015

43 Hasil wawancara dengan Guru Bimbingan dan Konseling Ibu Nurkamila Anggraini pada tanggal 03 Maret 2015

${ }^{44}$ Ibid.,

${ }^{45}$ Syamsu Yusuf dan A. Juntika Nurihsan, Layanan Bimbingan dan Konseling, (Bandung: PT Remaja Rosdakarya, 2010), hal. 241. 
Guru BK mengajak berkomunikasi (berbicara empat mata), memahami permasalahan siswa, mengerti cara berpikir dan perilakunya, serta menjadi pendengar yang baik. Dengan pendekatan tersebut, siswa sedikit demi sedikit merasa dekat dan nyaman dengan adanya guru BK. ${ }^{46}$ Dengan demikian, pelaksanaan bimbingan konseling dalam membina ESQ Siswa Berkebutuhan Khusus (SBK) dapat berjalan dengan baik.

Kedua, Guru BK sebagai pendamping. SBK memiliki keadaan emosional dan spiritual yang berbeda-beda. Setelah teridentifikasi masalah-masalah emosional dan spiritual yang dialami siswa, maka guru BK melakukan penyesuaian. Penyesuaian ini dimaksudkan untuk memahami kecenderungan siswa dalam masalah emosional dan spiritual. Untuk masalah emosional, jika siswa mengalami kesulitan dalam berkonsentrasi dan tidak dapat memahami pelajaran maka guru BK menjadi pendamping SBK dalam memahami materi dengan baik.

Untuk masalah spiritual, guru bimbingan konseling menyesuaikan kemampuan siswa dalam mengembangkan kecerdasan spiritualnya. Cara pendampingan yang dilakukan dengan memberikan pengetahuan-pengetahuan keagamaan sesuai dengan tingkat kemampuan mereka. Hal ini dikarenakan SBK memiliki tingkat kemampuan spiritual yang berbeda. Guru hanya membantu mengembangkan kemampuan mereka dengan pembiasaan. ${ }^{47}$

Ketiga, Guru BK sebagai motivator dan penasehat. Masalahmasalah emosional dan spiritual SBK yang telah teridentifikasi akan ditindak lanjuti oleh guru BK dengan memberikan dukungan atau motivasi agar siswa memiliki semangat untuk berkembang ke arah positif. Masalah kesulitan belajar umumnya disebabkan oleh kondisi emosi siswa yang kurang stabil, sehingga banyak siswa yang sulit berkonsentrasi dan tidak dapat memusatkan perhatiannya pada pelajaran. Dalam hal ini guru BK memberikan dorongan terhadap siswa agar memiliki kemauan untuk mengikuti pelajaran dengan baik.

Banyak SBK di SMP PGRI Kasihan yang sering membolos. Menurut Ibu Suginingsih selaku guru BK, kebanyakan siswa lakilaki yang tidak masuk sekolah tanpa keterangan beralasan lebih

46 Hasil wawancara dengan Guru Bimbingan dan Konseling Ibu Nurkamila Anggraini pada tanggal 03 Maret 2015

47 Hasil wawancara dengan Guru Bimbingan dan Konseling Ibu Suginingsih pada tanggal 03 Maret 2015 
memilih bermain di luar dengan teman-temannya seperti main game atau play station (PS). Dengan permasalahan ini, guru mengambil tindakan dengan mencari (mendatangi langsung) siswa yang membolos untuk mendapatkan keterangan dan penyebabnya. Guru memberikan pengarahan dan bimbingan individu terhadap siswa tersebut. Untuk masalah keagamaan, guru BK selalu mengingatkan untuk melakukan sholat lima waktu dan berdoa kepada Allah SWT agar diberi kemudahan dalam belajar. ${ }^{48}$

Keempat, Guru BK sebagai pembimbing dan konselor. Dalam membina ESQ bagi SBK, guru BK memberikan layanan bimbingan dan konseling dengan semaksimal mungkin. Bentuk bimbingan yang diberikan kepada SBK adalah bimbingan kelompok dan individu. Bimbingan kelompok diberikan secara klasikal, ditujukan agar siswa satu dengan yang lainnya dapat membaur dan mengenal dengan baik. Sedangkan bimbingan individu ditujukan agar guru bimbingan konseling dapat memberikan perhatian lebih dan mengontrol perilaku siswa berkebutuhan khusus. ${ }^{49}$

Kelima, Guru BK sebagai Pembangun Kerjasama. Ketika mengontrol (memantau) kemajuan siswa dalam hal emosional dan spiritual, guru BK selalu berkomunikasi dan bekerja sama dengan guru bidang studi, guru pendamping, maupun wali murid. Hal ini dilakukan agar semua pihak dapat memberikan perhatiannya dengan maksimal. ${ }^{50}$ Ada SBK yang hanya merasa nyaman dengan guru pendampingnya yaitu siswa autis Alvin Maulana Ilman kelas VII E. Menurut guru pendampingnya, Ibu Ida Farida, Alvin hanya akan menurut jika guru pendampingnya yang menasehati, membimbing, dan mengarahkan. ${ }^{51}$

Peran guru BK dalam membina ESQ bagi SBK membuahkan hasil yang cukup baik. Terlihat perkembangan perilaku dan akhlak siswa yang lebih baik. Hal ini dapat dilihat dari perbaikan secara bertahap pada kecerdasan emosional dan spiritual siswa. Pada awal masuk sekolah di kelas VII, mayoritas siswa sangat susah memahami pelajaran karena mereka berkesulitan belajar, namun dengan

${ }^{48}$ Ibid.,

49 Hasil wawancara dengan Guru Bimbingan dan Konseling Ibu Nurkamila Anggraini pada tanggal 03 Maret 2015

50 Hasil wawancara dengan Guru Bimbingan dan Konseling Ibu Suginingsih pada tanggal 03 Maret 2015

51 Hasil wawancara dengan Guru Pendamping Siswa Berkebutuhan Khusus Autis Ibu Ida Farida pada tanggal 10 April 2015 
adanya bimbingan yang terus-menerus, siswa lebih mampu untuk belajar dengan baik. ${ }^{52}$ SBK yang sulit dikendalikan seperti siswa autis, Alvin Maulana Ilman, setelah mendapatkan pendampingan dan bimbingan setiap hari, sudah mampu mengendalikan perilakunya sedikit demi sedikit. Saat awal masuk sekolah, Alvin sering berteriak-teriak, mengamuk, dan sulit memahami pelajaran. Namun, setelah mendapatkan perhatian khusus dari guru BK dan guru pendampingnya, menjadi lebih tenang dan memiliki kemauan untuk belajar. $^{53}$

\section{Faktor Penghambat dan Pendukung Implementasi BK dalam Membina ESQ bagi SBK di SMP PGRI Kasihan Bantul Yogyakarta}

Implementasi bimbingan konseling dalam membina kecerdasan emosional dan spitiritual siswa berkebutuhan khusus di SMP PGRI Kasihan tidak lepas dari adanya faktor penghambat dan pendukung sebagai berikut:

1. Faktor-faktor penghambat implementasi BK dalam membina ESQ bagi SBK ${ }^{54}$ yaitu: Pertama, perbedaan latar belakang keluarga dan orang tua SBK. Adanya perbedaan masalah latar belakang keluarga dan orang tua siswa berkebutuhan khusus dapat menghambat proses bimbingan dan konseling terlaksana dengan baik. Keadaan ekonomi keluarga dan orang tua siswasiswa berkebutuhan khusus mayoritas berada pada tingkat menengah ke bawah. Mereka memiliki pekerjaan dan kesibukannya masing-masing sehingga mayoritas siswa kurang mendapatkan perhatian atau dukungan dari orang tua. Selain itu, pendidikan dan latar belakang sosial yang kurang pada keluarga mengakibatkan kurangnya pemahaman dalam memberikan bimbingan kepada siswa berkebutuhan khusus secara maksimal. Tercapainya tujuan dalam membina kecerdasan emosional dan spiritual siswa berkebutuhan khusus tentu tidak akan berhasil jika bimbingan serta pendampingan yang maksimal tidak dilakukan pula ketika di rumah. Hal ini yang menuntut

${ }^{52}$ Hasil wawancara dengan Guru Bimbingan dan Konseling Ibu Suginingsih pada tanggal 03 Maret 2015

${ }^{53}$ Hasil wawancara dengan Guru Pendamping Siswa Berkebutuhan Khusus Autis Ibu Ida Farida pada tanggal 10 April 2015

${ }^{54}$ Hasil wawancara dengan Guru Bimbingan Konseling Ibu Suginingsih dan Ibu Nurkamila Anggraini pada tanggal 03 Maret 2015 
agar orang tua seharusnya lebih memperhatikan masalah emosional dan spiritual anaknya.

Kedua, perbedaan karakteristik individu SBK. Siswa-siswa berkebutuhan khusus memiliki kondisi kepribadian yang berbeda-beda dalam hal pembawaan, bakat, minat, motivasi, dan gaya belajar. Karakteristik siswa-siswa berkebutuhan khusus di SMP PGRI Kasihan adalah autisme, kelainan pendengaran, disleksia, slow learner (lambat belajar/kesulitan belajar), hiperaktif, dan cacat fisik. Sedangkan kesulitan-kesulitan yang mereka alami sehingga dapat dikatakan siswa berkebutuhan khusus adalah sulit memahami pelajaran, tidak bisa berkonsentrasi, kesulitan belajar, hiperaktif, suka mengganggu, banyak bercanda, sulit berkomunikasi, pasif, penakut, sulit berbicara, sulit membaca dan menulis, serta kurangnya kecerdasan emosional dan spiritual. Perbedaan individu siswa inilah yang membuat guru bimbingan konseling merasa kesulitan untuk mengontrol, berinteraksi, dan berkomunikasi kepada siswa berkebutuhan khusus.

Ketiga, keterbatasan waktu untuk melakukan pendampingan dan bimbingan. Pendidikan inklusi yang diterapkan di SMP PGRI Kasihan membuat siswa berkebutuhan khusus harus mendapatkan pembelajaran yang serupa atau sama dengan siswa reguler. Pengelompokan kelas mereka pun dicampur dan dijadikan satu dengan siswa normal lainnya. Hanya saja untuk tahun pelajaran baru 2014-2015, siswa kelas VII yang teridentifikasi sebagai siswa berkebutuhan khusus dan membutuhkan pendampingan ekstra dikelompokkan di kelas VII E. Namun karena kuota di kelas VII E penuh, maka masih ada beberapa siswa kelas VII yang belajar bersama siswa reguler. Untuk siswa berkebutuhan khusus kelas VIII dan IX, semua siswa berkebutuhan khusus belajar bersama siswa reguler. Oleh karena itu, waktu untuk mendapatkan bimbingan dan pendampingan ekstra bagi siswa berkebutuhan khusus sangat terbatas. Guru bimbingan konseling harus membagi waktu untuk memberikan layanan bimbingan bagi siswa berkebutuhan khusus dan siswa reguler. Hal ini yang membuat guru bimbingan konseling berkesulitan dalam memantau perkembangan siswa berkebutuhan khusus. 
Kendala-kendala tersebut dapat menghambat keberhasilan guru bimbingan konseling dalam membina kecerdasan emosional dan spiritual siswa berkebutuhan khusus. Walaupun demikian, kendala-kendala tersebut dapat ditanggulangi agar upaya dalam membina kecerdasan emosional dan spiritual bagi siswa berkebutuhan khusus dapat berjalan dengan baik. Hal ini dapat dilakukan dengan cara memaksimalkan faktor-faktor pendukung yang ada.

2. Faktor-faktor pendukung implementasi BK dalam membina ESQ bagi $\mathrm{SBK}^{55}$, yaitu: Pertama, semangat kerja guru BK dalam memberikan perhatian, motivasi, bimbingan, dan pendampingan secara kontinu. Dalam membina kecerdasan emosional dan spiritual bagi siswa berkebutuhan khusus, guru bimbingan konseling memberikan layanan bimbingan secara kontinyu. Layanan yang diberikan dalam bentuk bimbingan kelompok maupun individu. Hal ini ditujukan agar guru bimbingan konseling dapat memberikan perhatian, motivasi, bimbingan, dan pendampingan lebih kepada siswa berkebutuhan khusus. Dengan demikian, implementasi bimbingan konseling dalam membina kecerdasan emosional dan spiritual siswa berkebutuhan khusus dapat dilaksanakan dengan maksimal.

Kedua, partisipasi dari semua pihak sekolah dan wali murid. Upaya yang dilakukan guru bimbingan konseling untuk membina kecerdasan emosional dan spiritual siswa berkebutuhan khusus membutuhkan kerjasama dan dukungan dari semua pihak sekolah serta orang tua siswa. Oleh karena itu, demi kemajuan siswa dalam hal emosional dan spiritual, guru bimbingan konseling selalu berkomunikasi dan bekerja sama dengan kepala sekolah, wali kelas, guru bidang studi, guru pendamping, maupun wali murid. Hal ini dilakukan agar semua pihak berpartisipasi dalam memberikan perhatian, dukungan, bimbingan, dan pendampingannya secara maksimal.

Ketiga, kemauan siswa untuk berkembang ke arah yang lebih baik. Walaupun siswa-siswa berkebutuhan khusus di SMP PGRI Kasihan memiliki kekurangan dalam kemampuan emosional dan spiritual, namun banyak diantara mereka yang memiliki kemauan untuk berkembang menjadi lebih baik. De- 
ngan demikian, guru bimbingan konseling akan terus membantu dalam mengembangkan potensi-potensi yang dimiliki siswa. Jika siswa berpotensi dalam hal keagamaan seperti kemampuan membaca Al-Qur'an, guru bimbingan konseling bertugas untuk terus membantunya agar siswa mampu mengembangkan potensi yang dimiliki secara optimal. Begitu juga dalam hal mengelola emosi, guru bimbingan konseling akan terus mengembangkan kemampuan siswa agar dapat memanfaatkan emosinya secara produktif.

\section{Simpulan}

Berdasarkan pembahasan tentang peran guru bimbingan konseling dalam membina kecerdasan emosional dan spiritual siswa berkebutuhan khusus di SMP PGRI Kasihan Bantul Yogyakarta di atas, dapat disimpulkan bahwa: Pertama, kondisi kecerdasan emosional dan spiritual siswa berkebutuhan khusus di SMP PGRI Kasihan Bantul Yogyakarta memiliki sisi negatif dan positif, diantaranya : (a) Kondisi kecerdasan emosional: kurang dapat memanfaatkan emosi dengan baik, belum mampu mengelola emosi dengan baik, kurang percaya diri dan tidak berani menunjukkan potensi yang dimiliki, namun SBK memiliki sikap empati. (b) Kondisi kecerdasan spiritual: belum mampu menjalankan ibadahnya dengan baik, belum mampu membaca Al-Qur'an, kurangnya akhlak dan perilaku yang baik, namun mampu berbuat baik kepada kedua orang tua (Birrul Walidain).

Kedua, peran guru BK dalam membina ESQ bagi SBK di SMP PGRI Kasihan Bantul Yogyakarta yaitu: komunikator, pendamping, motivator dan penasehat, pembimbing dan konselor, serta pembangun kerjasama dengan semua pihak sekolah maupun wali murid. Ketiga, faktor penghambat yang dapat menghalangi pelaksanaan BK dalam membina ESQ bagi SBK di SMP PGRI Kasihan meliputi: (a) Perbedaan latar belakang keluarga dan orang tua siswa berkebutuhan khusus; (b) Keadaan individu siswa berkebutuhan khusus yang memiliki karakteristik yang berbeda-beda; dan (c) Keterbatasan waktu untuk melakukan pendampingan dan bimbingan. Namun kendala-kendala ini dapat ditanggulangi dengan cara memaksimalkan faktor-faktor pendukung, agar upaya dalam membina kecerdasan emosional dan spiritual siswa berkebutuhan khusus di SMP PGRI Kasihan dapat berjalan dengan maksimal. Faktor-faktor pendukung tersebut meliputi: (a) Guru bimbingan 
konseling selalu memberikan perhatian, motivasi, bimbingan, dan pendampingan secara kontinyu; (b) Adanya partisipasi dari semua pihak sekolah dan wali murid; dan (c) Adanya kemauan siswa untuk berkembang ke arah yang lebih baik.

\section{Kepustakaan}

Anonim, Undang-Undang Republik Indonesia Nomor 20 Tahun 2003 tentang Sistem Pendidikan Nasional.

Goleman, Daniel, Kecerdasan Emosional, Jakarta: PT Gramedia Pustaka Utama, 1996.

Gunawan, Heri, Keajaiban Berbakti kepada Kedua Orang Tua, Bandung: PT Remaja Rosdakarya, 2014.

Hermawan, Acep, 'Ulumul Qur'an; Ilmu untuk Memahami Wahyu, (Bandung: PT Remaja Rosdakarya, 2013.

N, Syamsu Yusuf L, Psikologi Perkembangan Anak dan Remaja, Bandung: PT Remaja Rosdakarya, 2008.

Nggermanto, Agus, Quantum Quotient; Kecerdasan Quantum Cara Praktis Melejitkan IQ, EQ, dan SQ yang Harmonis, Bandung: Nuansa, 2001.

Purnomo, Sigit, Bimbingan Konseling dalam Ontologi, Yogyakarta: Gala Ilmu Semesta, 2011.

Siswanto, Wahyudi, dkk., Membentuk Kecerdasan Spiritual Anak; Pedoman Penting bagi Orang Tua dalam Mendidik Anak, Jakarta: Amzah, 2010.

Syah, Muhibbin, Psikologi Pendidikan dengan Pendekatan Baru, Bandung: PT Remaja Rosdakarya, 2006.

Tasmara, Toto, Kecerdasan Ruhaniah (Tracendental Intelegence) Membentuk Kepribadian yang Bertanggung Jawab, Profesional, dan Berakhlak, Jakarta: Gema Insani Press, 2001

Tohirin, Bimbingan dan Konseling di Sekolah dan Madrasah, Jakarta: PT Raja Grafindo Persada, 2009.

Yusuf, Syamsu dan Nurihsan, A. Juntika, Layanan Bimbingan dan Konseling, Bandung: PT Remaja Rosdakarya, 2010.

Hasil wawancara dengan Guru Bimbingan dan Konseling Ibu Nurkamila Anggraini pada tanggal 03 Maret 2015 
Hasil wawancara dengan Guru Bimbingan Konseling Ibu Suginingsih pada tanggal 06 Januari 2015

Hasil wawancara dengan Guru Pendamping Siswa Berkebutuhan Khusus Ibu Yuni Asih pada tanggal 24 April 2015

Hasil wawancara dengan Guru Pendamping Siswa Berkebutuhan Khusus Autis (Alvin Maulana Ilman kelas VII E) pada tanggal 10 April 2015

Hasil wawancara dengan Guru Pendamping Siswa Berkebutuhan Khusus Autis Ibu Ida Farida pada tanggal 10 April 2015

Hasil wawancara dengan Kepala Sekolah Ibu Titi Surarawati pada tanggal 20 Februari 2015

Hasil wawancara dengan Kepala Sekolah Ibu Titi Surarawati pada tanggal 20 Februari 2015 